\title{
Investigation on Autolytic Processes and Microstructural Changes in Red Deer Meat
}

\author{
Leila A. Kaimbayeva ${ }^{1, *}$, Elena S. Malysheva ${ }^{2}$, Rashit Kazikhanov ${ }^{3}$ and \\ Saule R. Kazikhanova ${ }^{4}$ \\ ${ }^{1}$ Department of Chemistry and Chemical Technologies, North Kazakhstan State \\ University, Petropavlovsk, Republic of Kazakhstan \\ ${ }^{2}$ Barnaul Veterinary Department of the Altai Region State Veterinary Service, \\ Barnaul, Russian Federation \\ ${ }^{3}$ Department of Production Technology and Processing of Livestock, Saken Seifullin \\ Kazakh Agrotechnical University, Astana, Republic of Kazakhstan \\ ${ }^{4}$ Department of Hunting and Fisheries, Saken Seifullin Kazakh Agrotechnical \\ University, Astana, Republic of Kazakhstan
}

\begin{abstract}
A B S T R A C T
This study was designed to evaluate markers of autolysis and to effectively assess the optimal maturity of red deer meat before trading, and utilization in the production of meat products. For these purposes, meat samples were collected from quadriceps of 2.5-4 years old female red deer, immediately processed for isolation of muscular fibers and were evaluated for the $\mathrm{pH}$, water-binding power, activities of tissue enzymes and microstructure changes. The results of chemical analysis revealed the nature of protein substances, altered $\mathrm{pH}$ value of the meat and the intensity of glycolysis. All these parameters were indicative of autolysis process in the meat. The levels of water-binding capacity and structuralmechanical properties of red deer meat that occurred during the course of autolysis were further confirmed by the histological changes in the meat. Specifically, it was observed that post-mortem changes were characterized by multiple destruction and disintegration of fibers in the muscular tissue, and lysing of cores and their structures. Collectively, these results clearly articulate the irreversible destructive changes in the lean tissue. The data presented in this study highlight the mechanisms of the autolytic process and its influence both on the morphological composition of the lean tissue and on the shelf life of the meat.
\end{abstract}
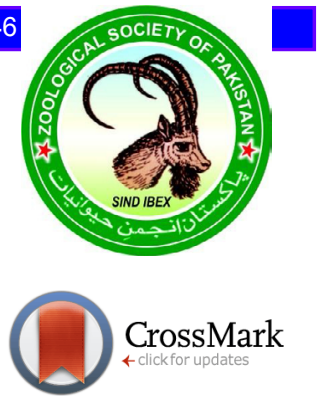

\section{INTRODUCTION}

$\mathrm{P}$ roduction of quality red deer meat though selective breeding and high-technology processing has positive knock on effects on the economies of developing countries including Republic of Kazakhstan. Specifically, the mountains and the piedmont parts of the Altai Territory and the East Kazakhstan Region are unique natural and climatic zones that favour the breeding of central anthlers red deer. While meat and meat-products are important source of food especially for poor communities, the meat productivity and quality of Altai red deer has not been studied comprehensively.

Recent studies have indicated that functional and technological properties of raw materials as well as the implementation of advanced technologies for the production and processing of red deer meat are inevitable and invaluable for food security (Satija et al., 2017).

\footnotetext{
* Corresponding author: dr.kaim2017@yandex.ua 0030-9923/2018/0004-1341 \$9.00/0

Copyright 2018 Zoological Society of Pakistan
}

Owing to high-grade and high-quality raw material, red deer meat offers an enormous sources of food with acceptable biological value (Abbas et al., 2017).

According to its biochemical properties, the red deer meat is characterized by high correlation of native proteins to deficient proteins, large content of nitric extractive matters, vitamins, macro- and microelements (Bureš et al., 2015). Thus, according to the content of such nonreplaceable amino acids as lysin and leucine, the red deer meat exceeds beef, pork and lamb (Kaimbaeva and Gurinovich, 2016). Due to the fact that there is a steady demand for this commodity, the quality of the meat is considered an important selection criterion (Kaimbaeva, 2008). One of the conditions of quality formation and product yield is the level and development nature of the autolytic processes (Kaimbaeva and Uzakov, 2015). Study of tissue composition will allow identifying functional and technological indicators of red deer meat quality (Malysheva and Zhukov, 2013).

In order to define benchmark of quality, the onset of autolysis was studied in red deer meat. Several indicators including $\mathrm{pH}$, water-binding power, activity of tissue 
enzymes and microstructural changes were assessed to propose the optimal periods of red deer meat maturation. These findings are fundamental to not only improve the quality of by-products but also to offer the most suitability time for processing of red deer meat.

\section{MATERIALS AND METHODS}

\section{Terms of the study}

A female red deer (2.5-4 years) was euthanized by electric current $(50 \mathrm{~Hz})$ and bleeding. The muscular tissues were collected from the quadriceps and were immediately processed for muscle fibre collection. These samples were then individually packed and stored at $2-4^{\circ} \mathrm{C}$ temperature until further analysis.

The first sampling was performed within 2-3 hours post-euthanasia, and were regarded as zero point in the analysis, representing a change of the studied indicators. The meat was considered fresh when it was maintained at the temperature of $35-36^{\circ} \mathrm{C}$. Afterward the sample analysis was performed at $30 \mathrm{~min}$, and 24, 48, 72, 96 and 120 hours post-euthanasia. For the potentiometric measurement of the active acidity in the meat, a $\mathrm{pH}$ tester millivoltmeter was used ( $\mathrm{pH}-150)$.

\section{Permission on Animal Handling and Euthanasia}

The experiments were carried out in accordance with the requirements of the European Convention for the Protection of Vertebrate Animals used for Experimental and Other Scientific Purposes and were approved by the Ethics Committee of the Saken Seifullin Kazakh Agrotechnical University (Protocol No. 1289-RM (November 18, 2017)).

\section{Methodologies}

In order to define the activity of proteinase, the Anson method was used (with modification of E. Kaverzneva), where the catalytic properties are judged by the degree of splitting of protein standard with the formation of low molecular weight products: peptides and amino acids, in particular, with regards to accumulation of tyrosine. Casein was used as a substrate when defining the activity of cathepsin D and calpain (Antipova et al., 2000).

The yield point (YP, Pa) was defined with the help of the device PM-3 (Antipova et al., 2000). The waterbinding power (WBP \%) was defined by the compaction method (Antipova et al., 2000). Histological examinations were conducted according to Standards of Organisation Federal State-Funded Educational Institution of Higher Professional Education 00493184-001-2013 'Red deer meat (Gnat et al., 2015). For histological examination, the traditional methodology was used for cross-sectioning of tissues. Following staining approach was applied; formalin- fixation of the samples within 7 days; carry-through by alcohol solutions, starting with $50 \%$ of concentration and finishing with $100 \%$, with the interval of $4-6 \%$ and the length of each stage of experiment of $24 \mathrm{~h}$; filling with paraffin within 6-10 days and weight fraction of $8-12 \%$ within 3-5 days. The cross-section of the samples was performed at the sledge microtome for further histological examinations after staining with heamatoxilin-eosin.

\section{Measuring instruments}

The received preparations were studied with the help of the miscroscope, Biolam P1Y4, under the object lens of $3.2-40$ with the increase of the ocular to $13 \mathrm{x}$. Further on, the analysis of the microscopical changes in the norm and in the post-mortem condition was performed with the help of micronets and a microruler (Russian Federation, 2013).

\section{RESULTS AND DISCUSSION}

Changes in the physico-chemical (pH, units), functionaltechnological (WBP, \%) and structural-mechanical (YP, Pa) indicators of red deer meat were studied in studying during the process of autolysis. The data represented in Table I showed that during the process of autolysis, the waterbinding capacity of red deer meat in the fresh state, under the temperature of $37^{\circ} \mathrm{C}$, is equal to $66.80 \%$. However, within an hour it was decreased insignificantly dropped as low as $65.20 \%$.

After $24 \mathrm{~h}$, the red deer meat revealed the WBP indicators of $52.32 \%$, and after $72 \mathrm{~h}$ - the value dropped to $54.6 \%$. With the following resolution of the post-mortem carcass stiffening, an increase of the hydration of the muscular tissue occured. The minimum of the hydration of proteins in the muscular tissue as marked approximately post 20-24 h of slaughtering.

The water-binding capacity of the meat after the carcass stiffening was continuously and slowly observed. The waterbinding capacities increased during the whole period of its storage under positive temperatures. However, it failed to reach the initial level of the fresh meat and approached its maximum level of $85-87 \%$. The reduction of waterbinding capacity in the muscular tissue within the first 24 $\mathrm{h}$ post-euthanasia was conditioned due to the reduction of $\mathrm{pH}$ value and the formation of actomyosin. It leads to the reduction of yield during the thermal treatment of meat and meat products. This is one of the most important practical consequences of stiffening.

The active-acidity of red deer meat at the beginning of autolysis approached to 5.6 units and after $24 \mathrm{~h}$ it reached its maximum value of 5.2 units. After 96 and $120 \mathrm{~h}(5$ days) it was stabilized to the value of 5.5 units (Table I). In connection with this, the process of autolysis was not studied after 5 days. 
Table I.- Changes of structural-mechanical and functional-technological indicators of red deer meat during the process of autolysis.

\begin{tabular}{lccc}
\hline Length of autolysis $(\mathbf{h})$ & $\mathbf{p H}$ & $\mathbf{W B P}(\%)$ & YP (Pa) \\
\hline $30 \mathrm{~min}$ & 5.6 & $66.80 \pm 0.26$ & $308 \pm 2.52$ \\
24 & 5.2 & $52.32 \pm 0.56$ & $312 \pm 2.52$ \\
48 & 5.3 & $53.35 \pm 0.62$ & $315 \pm 2.54$ \\
72 & 5.4 & $54.6 \pm 0.72$ & $330 \pm 2.64$ \\
96 & 5.5 & $56.6 \pm 0.68$ & $350 \pm 2.66$ \\
120 & 5.5 & $57.24 \pm 0.82$ & $360 \pm 2.89$ \\
\hline
\end{tabular}

During the maturing of meat, changes of structuralmechanical indicators occurred mainly as a result of biochemical transformations in the albuminous system (Rogov et al., 2013). Changes in the structural-mechanical indicators characterise tenderness of the meat (Nikiforova et al., 2011). The maturing process of processed meat is closely connected with the influence of proteolytic enzymes on the structural elements of tissues (Kudryashov, 2007). This fact proves the correlation between changes of protein substances, carbohydrates and mineral composition of the meat occurring during the maturing process (Cocolin, 2011).

The structural-mechanical indicators of red deer meat were assessed every hour within 5 days $(120 \mathrm{~h})$ after the killing, according to the results of yield strength. The received data showed that the structural-mechanical indicators of the muscular tissue of red deer meat depend on the structure of tissues and depth of development with regards to the autolytic processes. The results of performed experiments showed that the strength properties of the lean red deer meat is defined by the nature and depth of development of the said autolytic processes and depend considerably upon the grain of the tissues (Wiklund et al., 2014). Upon the death-mediated stiffening, the strength characteristics of the meat increased. As the obtained data confirmed, the changes of strength properties of red deer meat at the end of maturing has a tendency towards reduction. This process is explained by the conformational changes of the actomyosin complex and polyunsaturated fatty acids during the post-mortem period (Damez, 2008).

During the process of post-mortem changes, fermentative autolytic changes occur in the muscular tissue in the livestock, leading to the improvement of structuralmechanical indicators of the meat (Dutson, 1980). The tissue softening and the improvement of structuralmechanical indicators of the meat during the maturing stage are connected with the proteolytic degradation of protein structures under the influence of tissue proteolytic enzymes (Dwinger-Ron, 2008). The autolysis of meat occurs with the active participation of lysosome enzymescathepsins and calpains (Hope-Jones, 2010).

One of the conditions of quality and yield formation for the product would be the level and characteristics of development with regards to the autolytic processes (Krause, 2011). Study of the properties of the tissue proteinases will systematically change functionalstructural indicators of red deer meat (Cheret, 2007). With regards to this, the changes in the activity of tissue proteinases of red deer meat are studied according to the stages of the autolysis process.

The research into the activity of tissue enzymes were also assessed - with regards to cathepsins and calpains - in the muscular fiber of red deer meat. The proteolytic activity of cathepsin D and calpains were expressed in micrograms $(\mu \mathrm{m})$ of tyrosine during one hour for one gram (g) of tissue.

Results of the conducted research showed that during the process of autolysis, the release of cathepsins in the muscular tissues of red deer occurs as well as the manifestation of its activity (Fig. 1). The growth of free activity of cathepsin D is defined by the speed and depth of glycolytic changes. The data represented in Figure 1 confirmed the low activity of cathepsin D within 2-3 h after the slaughter of the animal. The low activity of cathepsin $\mathrm{D}$ after the slaughter is explained by the presence of native membrane in the meat retaining the cathepsines in the latent state.

During further maturing, the lysosome membrane permeability was increased and an active release of cathepsin $\mathrm{D}$ was observed as well as increase in the concentration of hydrogen ions in the sarcoplasm of the muscular fiber.

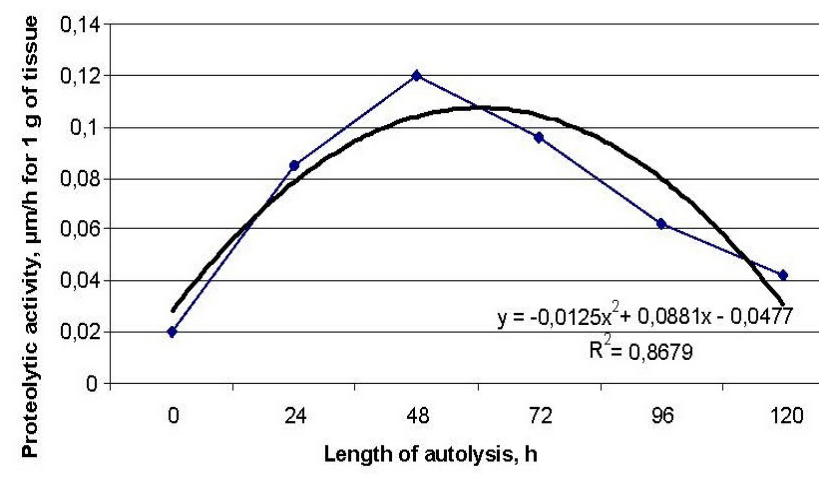

Fig. 1. Correlation of proteolytic activity of cathepsin D in the muscular fibers of red deer meat with regards to the length of autolysis. 
Table II.- Quantitative indicators of striated musle tissue of red deer females in the norm and in the post-mortem state.

\begin{tabular}{|c|c|c|c|c|c|c|}
\hline \multirow{2}{*}{$\begin{array}{l}\text { Time after the } \\
\text { slaughter }\end{array}$} & \multicolumn{2}{|c|}{ Diameter $(\mu \mathrm{m})$} & \multicolumn{2}{|c|}{ Area $\left(\mu m^{2}\right)$} & \multicolumn{2}{|c|}{ Relative volume (\%) } \\
\hline & Muscular fibers & Nucleus & Muscular fibers & Nucleus & Muscular fibers & Nucleus \\
\hline Carcass meat & $93.2-95.7$ & $15.6-19.8$ & $396.2-511.2$ & $2.8-3.6$ & 100 & 100 \\
\hline $24 \mathrm{~h}$ & $89.4-90.2$ & $13.2-17.6$ & $359.9-450.4$ & $1.8-2.5$ & 95.1 & 20.5 \\
\hline $48 \mathrm{~h}$ & $72.3-85.8$ & $12.1-16.5$ & $305.5-420.7$ & $1.2-2.3$ & 83.7 & 14.0 \\
\hline $72 \mathrm{~h}$ & $61.6-79.8$ & $9.7-13.6$ & $260.1-396.2$ & $1.2-1.8$ & 78.0 & 11.5 \\
\hline $96 \mathrm{~h}$ & $57.2-72.2$ & $7.1-12.1$ & $235.9-305.5$ & $1.4-1.7$ & 72.2 & 10.5 \\
\hline $120 \mathrm{~h}$ & $38.3-59.4$ & $4.4-8.6$ & $223.8-275.2$ & $0.6-0.9$ & 78.0 & 5.0 \\
\hline
\end{tabular}

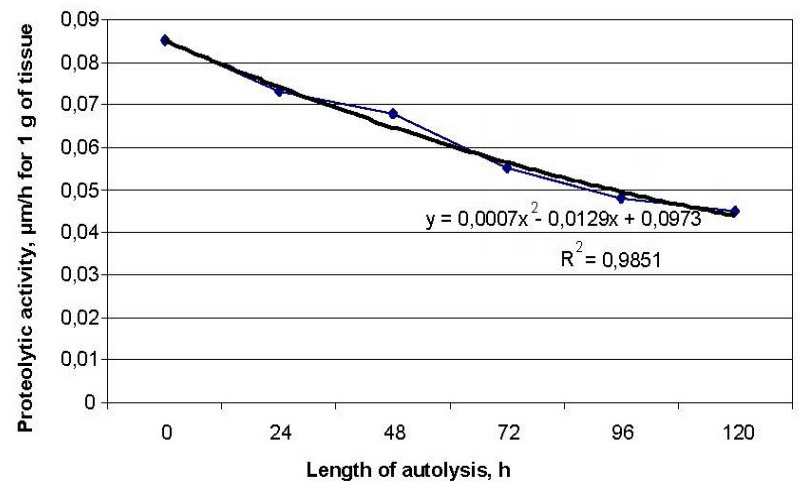

Fig. 2. Correlation of proteolytic activity of calpain in the muscular fibers of red deer meat with regards to the length of autolysis.

The maximum growth of proteolytic activity of cathepsin $\mathrm{D}$ for red deer meat was observed within 48 $\mathrm{h}$ after the slaughter $-0.12 \mu \mathrm{m} / \mathrm{h}$ for one gram of the protein. In the following hours of maturing, the enzyme inactivation occurred due to hydroxylation of hydrogen ions in the sarcoplasm of the muscular fiber.

The optimum proteolytic activity of calpains was observed in the fresh meat of red deer $-0.085 \mu \mathrm{m} / \mathrm{h}$ for one gram of protein (Fig. 2). The proteolytic activity of calpains is decreased sharply on the 2 nd and 3rd days of the maturing process, whereas on the 4th and 5 th days it is being stabilised (Skibniewski and Skibniewska, 2015). This process might be explained by the autoproteolysis and presence of an inhibitor of calpain enzyme - calpastatin.

It was revealed that the correlation of the activity of calpains with regards to $\mathrm{Ca} 2+$ might support the functionality of a regulatory mechanism, due to a change of the cation level in the cells and participation of $\mathrm{Ca} 2+$ - activated neutral proteases in the limited proteolysis. These changes in turn lead to altered activity of a number of enzymes (Krause, 2011). The quantitative indicators of the striate muscle tissue of female red deer in the normal and the post-mortem states are shown in Table II.

The outcome of performed experiments showed that the strength properties of the muscular fibers of red deer are defined by the nature and depth of development of autolytic processes and depend considerably on the structure of the tissues. Upon the start of death stiffening, the strength properties of the meat enhanced whereas changes in the strength properties of red deer meat at the end of maturing process has a tendency to decline (Cordeiro et al., 2017; Laghi et al., 2017). This circumstance is explained by the conformational changes of the actomyosin complex and polyunsaturated fatty acids during the post-mortem period. It was determined by the conducted research that the nature of changes of protein substances in the process of autolysis is determined by the $\mathrm{pH}$ value of the meat and the intensity of glycolysis (Dervilly-Pinel et al., 2017; Fowler et al., 2018; Prieto et al., 2017). The analysis of water binding capacity and structural-mechanical properties of red deer meat in the process of autolysis agreed with the results of the histologic examinations. The results of the quantitative investigations of histological sections of the muscular fiber of red deer females testify to the fact that the maximum diameter of the muscular fiber $(95.7 \mu \mathrm{m})$, as well as the diameter of cell nuclei $(19.8 \mu \mathrm{m})$ is peculiar for the samples received $30 \mathrm{~min}$ after the slaughter.

The maximum area occupied by the muscular fibers during this period was equal to $511.2 \mu \mathrm{m} 2$, whereas the area occupied by the nuclei makes up $3.6 \mu \mathrm{m} 2$. We can observe the least diameter of the muscular fibers $(59.4 \mu \mathrm{m})$ and the diameter of cell nuclei $(8.6 \mu \mathrm{m}) 120 \mathrm{~h}$ after the slaughter. Under the post-mortem conditions, after $120 \mathrm{~h}$, the area occupied by the muscular fibers made up 275.2 $\mu \mathrm{m} 2$, and the area taken by the nuclei was equal to 0.9 $\mu \mathrm{m} \mathrm{2}$. A total of $24 \mathrm{~h}$ after the slaughter, the diameter of muscular fibers decreased by $5.5 \%$, whereas the diameter of nuclei decreased by $2.2 \%$.

During the process of changes post-death, under the influence of own enzymes, the disintegration of muscular 
fibers and karyolysis was observed. The quantitative indicators were also changed during the process of autolysis (Myshalova et al., 2016). Therefore, $48 \mathrm{~h}$ posteuthanasia, the diameter of muscular fibers was decreased by $5.6 \%$, whereas the diameter of nuclei was decreased by $1.1 \%$. Later on, throughout the duration of $72 \mathrm{~h}, 96 \mathrm{~h}$, the diameter of the muscular fiber and the nuclei decreased by $6-2.9 \% ; 7.6-1.5 \%$ correspondingly. Upon completion of our experiment, during the process of autolysis, the diameter of muscular fibers decreased by $36.3 \%$, diameter of nuclei decreased by $11.6 \%$; the area occupied by the muscular fibers was reduced by $43.5 \%$, whereas the area occupied by nuclei was reduced by $2.7 \%$.

\section{CONCLUSION}

In conclusion, the obtained results indicated that changes after death are characterized by the multiple destruction and disintegration of the muscular fibers, lysing of nuclei and their structures. Afterwards, all of these characteristics lead to irreversible destructive changes of the lean tissue. Thus, the mechanisms of the autolytic processes influence both the morphological composition of the lean tissue and the shelf life of the meat for processing.

\section{Statement of conflict of interest}

Authors have declared no conflict of interest.

\section{REFERENCES}

Abbas, G., Nadeem, A., Babar, M.E., Hussain, T., Tahir, M.S., Shehzad, W., Iqbal, R.Z., Tayyab, M. and Javed. M. 2017. Molecular phylogeny and diversity analysis of hog deer (Axis porcinus) in Pakistan. Pakistan J. Zool., 49: 1701-1712. http://dx.doi. org/10.17582/journal.pjz/2017.49.5.1701.1712

Antipova, L.V., Glotova I.A. and Zharinov, A.I., 2000. Meat and meat products test methods. Voronezh State Technological Academy Press, Voronezh, pp. 14-18.

Bureš, D., Bartoň, L. and Kotrba, R. and Hakl, J., 2015. Quality attributes and composition of meat from red deer (Cervus elaphus), fallow deer (Dama dama) and Aberdeen Angus and Holstein cattle (Bos taurus). J. Sci. Fd. Agric., 95: 2299-2306. https://doi.org/10.1002/jsfa.6950

Cheret, R., 2007. Calpain and cathepsin activities in postmortem fish and meat muscles. Fd. Chem., 101: 1474-1479. https://doi.org/10.1016/j. foodchem.2006.04.023

Cordeiro, R.A., Sales, J.A., Castelo-Branco, D.S.C.M.,
Brilhante, RSN., Ponte, Y.B., Dos Santos Araújo, G., Mendes, P.B.L., Pereira, V.S., Alencar, L.P., Pinheiro, A.Q., Sidrim, J.J.C. and Rocha, M.F.G., 2017. Candida parapsilosis complex in veterinary practice: A historical overview, biology, virulence attributes and antifungal susceptibility traits. Vet. Microbiol., 212: 22-30.

Cocolin, L., 2011. Biodiversity and dynamics of meat fermentations: The contribution of molecular methods for a better comprehension of a complex ecosystem. Meat Sci., 89: 296-302. https://doi. org/10.1016/j.meatsci.2011.04.011

Damez, J.L., 2008. Meat quality assessment using biophysical methods related to meat structure. Meat Sci., 80: 132-149. https://doi.org/10.1016/j. meatsci.2008.05.039

Dervilly-Pinel, G., Guérin, T., Minvielle, B., Travel, A., Normand, J., Bourin, M., Royer, E., Dubreil, E, Mompelat, S., Hommet, F., Nicolas, M., Hort, V-, Inthavong, C., Saint-Hilaire, M., Chafey, C., Parinet, J., Cariou, R., Marchand, P., Le Bizec, B., Verdon, E. and Engel, E., 2017. Micropollutants and chemical residues in organic and conventional meat. Food Chem., 232: 218-228.

Dutson, J.R., 1980. Lysosomal enzyme distribution in electrically stimulated bovine muscle. J. Fd. Sci., 45: 1097-1099. https://doi. org/10.1111/j.1365-2621.1980.tb07533.x

Dwinger-Ron, H., 2008. Meat safety: Regulatory aspects in the European Union. Meat Biotechnol., 4: 453-465. https://doi.org/10.1007/978-0-38779382-5_20

Fowler, S.M., Schmidt, H., de Ven, R. and Hopkinsa, D.L., 2018, Preliminary investigation of the use of Raman spectroscopy to predict meat and eating quality traits of beef loins. Meat Sci., 138: 53-58.

Gnat, S., Trościańczyk, A., Nowakiewicz, A., MajerDziedzic, B., Ziółkowska, G., Dziedzic, R., Zięba, P. and Teodorowski, O., 2015. Experimental studies of microbial populations and incidence of zoonotic pathogens in the faeces of red deer (Cervus elaphus). Lett. appl. Microbiol., 61: 446452. https://doi.org/10.1111/lam.12471

Hope-Jones, M., 2010. The efficiency of electrical stimulation to counteract the negative effects of $\beta$-agonists on meat tenderness of feedlot cattle. Meat Sci., 86: 699-705. https://doi.org/10.1016/j. meatsci.2010.06.008

Kaimbaeva, L.A. and Gurinovich G.V., 2016. Study of autolytic changes in red deer meat and beef. Indian J. Sci. Technol., 9: 1-8. https://doi.org/10.17485/ ijst/2016/v9i30/98747 
Kaimbaeva, L.A. and Uzakov, Y.M., 2015. The use of red deer meat and by-products in production of meat products. Meat Indust., 8: 40-43.

Kaimbaeva, L.A., 2008. Qualitative characteristics and chemical composition of red dear meat. Bull. agric. Sci. Kazakhstan, 9: 5-57.

Krause, J., 2011. Purification and partial characterization of ostrich skeletal muscle cathepsin D and its activity during meat maturation. Meat Sci., 87: 196201. https://doi.org/10.1016/j.meatsci.2010.10.009

Kudryashov, L.S., 2007. Enzymes of muscle tissue and their properties. Meat Indust., 9: 18-21.

Laghi, L., Venturi, L., Dellarosa, N. and Petracci, M., 2017. Water diffusion to assess meat microstructure. Food Chem., 236: 15-20.

Malysheva, E.S. and Zhukov, V.M., 2013. Peculiarities of microstructural changes of the lean tissue of red deer females during the post-mortem period. Cattle Breed., 2: 82-84.

Myshalova, O.M., Gurinovich, G.V. and Gurikov Y.S., 2016. Integrated research of maral meat for substantiation of use in the technology of delicacy products. Tech. Technol. Food Prod., 3: 38-43.

Nikiforova, A.P., Hanhalaeva, I.A. and Hamaganova, I.V., 2011. Beef product development using the QFD method. Fd. Technol. Market. Manage. Res., 2: 26-28.
Prieto, N., Pawluczyk, O., Dugan, M.E.R. and Aalhus J.L., 2017. A Review of the principles and applications of near-infrared spectroscopy to characterize meat, fat, and meat products. Appl Spectrosc., 7: 1403-1426.

Russian Federation, 2013. Red deer meat. Method of histological examination. Standard of Organisation, Federal State-Funded Educational Institution of Higher Profesional Education 00493184-001, Russian Federation.

Rogov, I.A., Danilchuk, T.N. and Abdrashitova, G.G., 2013. Structure at the nano level of fermented connective tissue of beef. Meat Indust., 6: 26-28.

Satija, A., Malik,V.S. and Willett, W.C., 2017. Metaanalysis of red meat intake and cardiovascular risk factors: Methodologic limitations. Am. J. clin. Nutr., 105: 1567-1568.

Skibniewski, E.M. and Skibniewska, T.K., 2015. The content of selected metals in muscles of the red deer (Cervus elaphus) from Poland Michat. Environ. Sci. Pollut. Res., 22: 8425-8431. https:// doi.org/10.1007/s11356-014-4007-0

Wiklund, E., Farouk, M. and Finstad, G., 2014. Venison: Meat from red deer (Cervus elaphus) and reindeer (Rangifer tarandus tarandus). Anim. Front., 4: 5561. https://doi.org/10.2527/af.2014-0034 